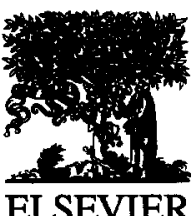

Agricultural and Forest Meteorology 84 (1997) 249-254

AGRICULTURAL

AND

FOREST

METEOROLOGY

\title{
Heat units to predict tomato harvest in the southeast USA
}

\author{
Katharine B. Perry ${ }^{\mathrm{a}, *}$, Yihua $\mathrm{Wu}^{\mathrm{a}}{ }^{\mathrm{a}}$, Douglas C. Sanders ${ }^{\mathrm{a}}$, J. Thomas Garrett ${ }^{\mathrm{b}}$, \\ Dennis R. Decoteau ${ }^{b}$, Russell T. Nagata ${ }^{b}$, Robert J. Dufault ${ }^{c}$, K. Dean Batal ${ }^{d}$, \\ Darbie M. Granberry ${ }^{\mathrm{d}}$, Wayne J. Mclaurin ${ }^{\mathrm{e}}$ \\ ${ }^{a}$ Department of Horticultural Science, North Carolina State University, Raleigh, NC 27695-7609, USA \\ ${ }^{\mathrm{b}}$ Department of Horticulture, Clemson University, Clemson, SC 29634, USA \\ ${ }^{c}$ Coastal Research and Education Center, Department of Horticulture, Clemson University, 2865 Savannah Highway, Charleston, SC \\ 29414, USA \\ d Department of Horticulture, University of Georgia, Tifton, GA 31793, USA \\ 'Department of Extension Horticulture, University of Georgia, Athens, GA 30602, USA
}

Received 5 July 1995; accepted 29 April 1996

\begin{abstract}
Planting and first harvest dates of tomato (Lycopersicon esculentum Mill.) from 2 seasons in 3 years at eight locations in Georgia, North Carolina and South Carolina formed 38 environments which were used to determine the most reliable method to predict first harvest date of tomato based on daily maximum and minimum air temperature. Eleven methods of calculating heat units were chosen for comparison based on their performance as described in the literature. The most reliable method was defined as the one with the smallest coefficient of variation $(\mathrm{CV})$. CVs were calculated for each method over both seasons and locations, for each season over all locations, each location over all seasons, and for each season at each location. All heat unit summation methods had smaller coefficients of variation (CV) than the standard method of counting days from planting to first harvest.

Heat unit summation methods improved harvest date prediction accuracy compared with the counting day method for tomatoes in the South Atlantic Coast (SAC) region. Prediction using location/season specific models were less variable than the models over all seasons and locations. Incorporating daylength improved model prediction accuracy when applied over all locations and seasons, all locations by season, and all seasons by location. Based on the results of this study, the heat unit summation technique recommended for this region (where the location and season specific models are not available) is the reduced ceiling method multiplied by daylength. (C) 1997 Elsevier Science B.V. All rights reserved.
\end{abstract}

Keywords: Heat units; Tomato harvest; Southeast USA; Air temperature

\section{Introduction}

Heat unit accumulation techniques have been applied to numerous vegetable production systems for

\footnotetext{
* Corresponding author.
}

predicting harvest date and timing of successive plantings (Boswell, 1929; Owens and Moore, 1974; Perry et al., 1986, Perry et al., 1993; Wolf et al., 1986; Dufault et al., 1989; Perry and Wehner, 1990). The heat unit requirements for tomato (Lycopersicon esculentum Mill.) harvest at several locations in the 
USA and around the world have been determined using the initial heat unit calculation method of calculating a daily mean air temperature from the maximum and minimum and subtracting a base temperature (Warnok and Isaacs, 1969; Warnok, 1970; Owens and Moore, 1974; Wolf et al., 1986; Calado and Portas, 1987). The objective of this study was to compare different methods of calculating heat units and determine the most reliable method to predict tomato harvest.

The optimal temperature for tomato growth and development ranges from 15 to $18^{\circ} \mathrm{C}$ night time and 18 to $27^{\circ} \mathrm{C}$ day time (Witter and Aung, 1969). However, the base temperatures reported for calculating heat units for tomatoes are much lower than $15^{\circ} \mathrm{C}$. Owens and Moore (1974) used $7^{\circ} \mathrm{C}$ as the base temperature to determine maturity of tomato. Warnok and Isaacs (1969) found that $4.3^{\circ} \mathrm{C}$ was the best base temperature for summation of tomato heat units in California. Calado and Portas (1987) reported that base temperatures at Azambuja, Coruche and Elvans, Portugal were 6,8 , and $10^{\circ} \mathrm{C}$, respectively. They found that base temperatures were lower for areas with higher temperature in early spring.

Owens and Moore (1974) found the most precise method of determining maturity of the cultivar Chico Grande in Scott, Mississippi to be the 'corrected mean' method with a $27^{\circ} \mathrm{C}$ ceiling and $7^{\circ} \mathrm{C}$ base. The corrected mean method averages the maximum and minimum temperature of a day and subtracts the difference between the maximum temperature and a ceiling temperature and then subtracts the base temperature. The ceiling temperature is the upper limit of the optimal growth temperature range. Wolf et al. (1986) described a model to predict the times of emergence, flowering, turning stage, and harvest of processing tomatoes based on an accumulation of heat units defined in terms of physiological days. They defined a physiological day as equivalent to a calendar day with a constant temperature of $26^{\circ} \mathrm{C}$. Accumulation of physiological days was based on a linear function during the first two stages, and quadratic function during the last two stages. Perry et al. (1986) and Perry and Wehner (1993) found that among 14 heat unit summation methods, the reduced ceiling method was the best to determine the harvest date of cucumber in the southeastern United States. The reduced ceiling method sums over days from planting to harvest the difference between the daily maximum and a base temperature; but if the maximum exceeds the ceiling temperature, it is replaced by the ceiling minus the difference between the maximum and the ceiling, before subtracting the base. Dufault et al. (1989) also found this reduced ceiling method produced the lowest coefficient of variation $(\mathrm{CV})$ when it was used to determine the heat unit requirements for predicting collard harvest in the same region. Tyldesley (1978) reported a method which incorporates a non-linear organism response to temperature, i.e. the organism response peaks near a certain temperature, declining for higher and lower temperatures. Tyldesley's method considers four cases: (1) temperature curve above base temperature all day, (2) temperature curve above base temperature more than below, (3) temperature curve below base temperature more than above, and (4) temperature curve below base temperature all day. Finally, Hodges (1991) stated that use of daylength might improve heat unit calculation methods.

\section{Materials and methods}

Spring and fall planting dates were selected with the goal of establishing earliest spring and latest fall production for the South Atlantic Coast (SAC) region (Table 1). These planting dates applied to eight locations in the SAC region of Georgia, North Carolina, and South Carolina (Table 2) were selected to represent 38 environments.

Four tomato cultivars, Pik Red, Blazer, Sunny, and Mountain Pride were evaluated in each location. We chose the cultivars based on commercial standards and previous field trials. Uniform plot size, experimental design, grading standards, and data collection were used in all locations. Individual plots were $6.1 \mathrm{~m}$ long and $1.5 \mathrm{~m}$ wide. Single rows of 5-week-old transplants were planted $45 \mathrm{~cm}$ in row and $1.5 \mathrm{~m}$ centers. A Latin square experiment design of cultivars was replicated four times. Commercially accepted fertilization based on soil tests, plastic mulch, drip irrigation, and pest management practices were used in all locations. Half of the $\mathrm{N}$ and $\mathrm{K}$ and all $\mathrm{P}$ materials were applied preplant. The remaining $\mathbf{N}$ and $K$ were applied weekly. Sufficient 
Table 1

Locations of South Atlantic Coast region plantings from Spring 1985 to Fall 1987

\begin{tabular}{|c|c|c|c|c|c|c|}
\hline $\begin{array}{l}\text { Location } \\
\text { (state) }\end{array}$ & $\begin{array}{l}\text { Geographic } \\
\text { region }\end{array}$ & $\begin{array}{l}\text { Elev. } \\
(\mathrm{m})\end{array}$ & $\begin{array}{l}\text { North } \\
\text { latitude }\end{array}$ & $\begin{array}{l}\text { West } \\
\text { longitude }\end{array}$ & $\begin{array}{l}\text { Soil } \\
\text { type }\end{array}$ & $\begin{array}{l}\text { Ave. } \\
\text { growing } \\
\text { season } \\
\text { (days) }\end{array}$ \\
\hline \multicolumn{7}{|l|}{ Georgia } \\
\hline Attapulgus & Lower SW coastal plain & 85 & $30^{\prime} 42^{\prime \prime}$ & $84^{\prime} 23^{\prime \prime}$ & $\begin{array}{l}\text { Norfolk loamy sand; fine loamy, siliceous thermic } \\
\text { Typic Kandiudult }\end{array}$ & 279 \\
\hline Plains & Central western coastal plain & 152 & $32^{\prime} 3^{\prime \prime}$ & $84^{\prime} 22^{\prime \prime}$ & $\begin{array}{l}\text { Greenville series; clayey, kaolinitic, thermic } \\
\text { Rhodic Kandiudult }\end{array}$ & 280 \\
\hline Tifton & Lower SW ccastal plain & 110 & $31^{\prime} 28^{\prime \prime}$ & $83^{\prime} 31^{\prime \prime}$ & $\begin{array}{l}\text { Tifton sandy loam; fine sandy, siliceous thermic } \\
\text { Plinthic Paleudult }\end{array}$ & 296 \\
\hline \multicolumn{7}{|c|}{ North Carolina } \\
\hline Fletcher & S. Appalachian Mountains & 631 & $35^{\prime} 26^{\prime \prime}$ & $82^{\prime} 34^{\prime \prime}$ & Delanco loam; Aquic Hapludult & 200 \\
\hline Lewiston & Tidewater coastal plain & 15 & $36^{\prime} 8^{\prime \prime}$ & $77^{\prime} 10^{\prime \prime}$ & $\begin{array}{l}\text { Norfolk sandy loam; fine sandy; siliceous thermic } \\
\text { Plinthic Paleudult }\end{array}$ & 210 \\
\hline \multicolumn{7}{|c|}{ South Carolina } \\
\hline Charleston & Lower eastern coastal plain & 3 & $32^{\prime} 47^{\prime \prime}$ & $79^{\prime} 56^{\prime \prime}$ & $\begin{array}{l}\text { Yauhannah fine loamy sand; siliceous thermic } \\
\text { Aquic Hapludult }\end{array}$ & 290 \\
\hline Clemson & Upper Piedmont & 250 & $34^{\prime} 41^{\prime \prime}$ & $82^{\prime} 49^{\prime \prime}$ & $\begin{array}{l}\text { Congaree silt loam; fine loamy, mixed, non-acid } \\
\text { thermic Typic Udifluvent }\end{array}$ & 205 \\
\hline Florence & Central upper coastal plain & 44 & $34^{\prime} 13^{\prime \prime}$ & $79^{\prime} 46^{\prime \prime}$ & Norfolk loamy sand; fine loamy, siliceous & 220 \\
\hline
\end{tabular}

irrigation was supplied to maintain available soil moisture near the plants at $80 \%$ of field capacity. Row middles were treated with $2 \mathrm{~kg} \mathrm{ha}^{-1}$ napromanide, and all beds were fumigated with $200 \mathrm{~kg}$ $\mathrm{ha}^{-1}$ of $98 \%$ methyl bromide. Tomatoes were harvested, weekly for 4 to 6 weeks depending on the location, when fruits were at the incipient color stage or ripening. Cultivars did not differ significantly in harvest date and therefore cultivar differences were not given further consideration for calculation of heat unit accumulations.

Daily maximum and minimum air temperatures were recorded by alcohol-in-glass thermometers in standard National Weather Service wooden, double

Table 2

Locations and planting dates of tomato from Spring 1985 through Fall 1987

\begin{tabular}{|c|c|c|c|c|c|c|c|c|}
\hline \multirow[t]{2}{*}{ Planting time ${ }^{a}$} & \multicolumn{3}{|l|}{ Georgia } & \multicolumn{2}{|c|}{ North Carolina } & \multicolumn{3}{|c|}{ South Carolina } \\
\hline & $\overline{\text { ATTA }}^{b}$ & PLNS & TIFT & FLET & LEWI & CHAS & CLEM & FLOR \\
\hline SP 11985 & & & & 15 May & $30 \mathrm{Apr}$. & & & \\
\hline SP 21985 & & & & & 16 May & & & \\
\hline FL 11985 & 6 Aug. & & 7 Aug. & 3 June & 18 July & 31 July & 18 July & \\
\hline SP 11986 & 17 Mar. & 24 Mar. & & 23 May & 5 May & 1 Apr. & 18 Apr. & $20 \mathrm{Apr}$ \\
\hline SP 21986 & & 9 Apr. & & & 20 May & & 1 May & \\
\hline FL 11986 & 19 Aug. & 12 Aug. & & 2 June & 14 July & 15 Aug. & 6 Aug. & \\
\hline FL 21986 & & & & 16 June & & & & \\
\hline SP 11987 & & 17 Apr. & & & 1 May & 23 Mar. & 23 Apr. & 17 Apr \\
\hline SP 21987 & & & & & 14 May & & 7 May & 1 May \\
\hline FL 11987 & & 13 Aug. & & 1 June & 22 July & & & \\
\hline FL 21987 & & & & 10 July & & & & \\
\hline
\end{tabular}

\footnotetext{
${ }^{a}$ SP, spring, planting before June 1; FL, fall, planting after June 1.1 and 2 indicate first and second plantings, respectively.

b ATTA, Attapulgus; CHAS, Charleston; CLEM, Clemson; FLET, Fletcher; FLOR, Florence; LEWI, Lewiston; PLNS, Plains; TIFT, Tifton.
} 
roofed, side louvered shelters at $1.5 \mathrm{~m}$ above the surface.

The growing season for tomatoes in the SAC region ranges from March to November. Summations of heat units in this study were determined based on 54 base and ceiling temperature combinations. Base temperatures were $0,2,4,6,8,10,12$, $14,16^{\circ} \mathrm{C}$, selected to be a range covering all the base temperatures studied by previous researchers. Ceiling temperatures were $26,28,30,32,34,36^{\circ} \mathrm{C}$, selected to be near and above the maximum optimal temperature (Witter and Aung, 1969).

Based on the previous findings described above, the following methods were selected as having the greatest potential for tomato harvest prediction dependability.

\subsection{Method I}

Standard degree day method

$\mathrm{GDD}=\Sigma\left(\left(T_{\mathrm{x}}+T_{\mathrm{n}}\right) / 2-\right.$ Base $)$

where $T_{\mathrm{x}}, T_{\mathrm{n}}$ are the daily maximum and minimum temperatures.

\subsection{Method 2}

Maximum instead of mean method

$\mathrm{GDD}=\Sigma\left(T_{\mathrm{x}}-\right.$ Base $)$

\subsection{Method 3}

Reduced ceiling method (Perry et al., 1986)

Eq. (2) $T_{x} \leq$ ceiling

GDD $=\Sigma\left(\left(T_{\mathrm{c}}-\left(T_{\mathrm{x}}-T_{\mathrm{c}}\right)\right)-\right.$ Base $) \quad T_{\mathrm{x}}>$ ceiling

i.e. if maximum is greater than the ceiling, $T_{\mathrm{c}}$, set maximum equal to the ceiling minus the difference between the maximum and ceiling.

\subsection{Method 4}

Owens and Moore (1974) method

$$
\begin{aligned}
& \mathrm{GDD}=\left(\left(\left(T_{\mathrm{x}}+T_{\mathrm{n}}\right) / 2-\left(T_{\mathrm{x}}-\text { Ceiling }\right)\right)-\text { Base }\right) \\
& T_{\mathrm{x}}>\text { ceiling }
\end{aligned}
$$

$$
\mathrm{GDD}=\left(\left(T_{\mathrm{x}}+T_{\mathrm{n}}\right) / 2-\text { Base }\right) \quad T_{\mathrm{x}} \leq \text { ceiling }
$$

\subsection{Method 5}

Tyldesley (1978) method

$$
\begin{aligned}
& \mathrm{GDD}=\left(\left(T_{\mathrm{x}}+T_{\mathrm{n}}\right) / 2-\text { Base }\right) \quad T_{\mathrm{n}}>\text { Base } \\
& \mathrm{GDD}=\left(1 / 2\left(T_{\mathrm{x}}-\text { Base }\right)-1 / 4\left(\text { Base }-T_{\mathrm{n}}\right)\right) \\
& \left(T_{\mathrm{x}}-\text { Base }\right)>\left(\text { Base }-T_{\mathrm{n}}\right)>0 \\
& \mathrm{GDD}=\left(1 / 4\left(T_{\mathrm{x}}-\text { Base }\right)\right) \\
& 0<\left(T_{\mathrm{x}}-\text { Base }\right)<\left(\text { Base }-T_{\mathrm{n}}\right) \\
& \mathrm{GDD}=0 \quad T_{\mathrm{x}}<\text { Base }
\end{aligned}
$$

\subsection{Methods 6 through 10}

Methods 1 through 5 multiplied by daylength (DL), e.g. Method 6 would be

$\mathrm{GDD}=\Sigma\left(\mathrm{DL}\left(T_{\mathrm{x}}+T_{\mathrm{n}}\right) / 2-\right.$ Base $)$

Daylength was the actual daylength of each day as calculated in Perry et al. (1986).

\subsection{Method 11}

Average number of days from planting to first harvest.

The coefficient of variation (CV) was used as recommended by Arnold (1959) to identify the best method for predicting days from planting to first harvest. CVs were calculated for each method over all seasons and locations, for each method over all locations for each season, and for each method in each season at each location.

\section{Results and discussion}

The analyses of the 11 methods, nine base temperatures, and six ceiling temperatures for all seasons and locations, for each season over all locations, for all seasons at each location, and for each season at each location show that the heat unit summation methods were less variable than the standard method 
of mean days to harvest in all cases (Table 3). Method 8 (reduced ceiling multiplied by DL) resulted in the least variation over all locations and both seasons.

Inclusion of daylength improved model prediction accuracy in most (13 of the 21 analyses) environments. Over all seasons and locations, daylength reduced model variability (decreased CV). Daylength reduced model variability for fall seasons over all locations. Daylength also reduced model variability at each location over all seasons except Clemson where the best combination of method/base/ceiling did not include daylength effect. Air temperature fluctuates more frequently and sharply in spring than in fall (as defined here, i.e. planting after June 1). Therefore, air temperature in spring is far more critical to tomato growth than the daylength.

The base temperature varied between spring and fall for the five locations (Charleston, Clemson, Fletcher, Lewiston, Plains) that allowed analysis of each season at the location (Table 3). This is due to the base temperature being influenced by the temperature range of the data from which it is determined (Arnold, 1959).

The best method (smallest CV), base and ceiling temperature combinations differed from location to

Table 3

The best combination of rnethod/base/ceiling and comparison to Method 8 when it was not the best, over all stations and both seasons, over all locations in each season, and for seven locations over both seasons and for each location in the Fall season and six locations in the Spring season

\begin{tabular}{|c|c|c|c|c|c|c|c|}
\hline \multirow[t]{2}{*}{ Location $^{a}$} & \multirow[t]{2}{*}{ Season } & \multirow[t]{2}{*}{ Number of environments } & \multicolumn{4}{|c|}{ Method with smallest CV } & \multirow[t]{2}{*}{ Counting day method CV (\%) } \\
\hline & & & No. & Base & Ceiling & $\mathrm{CV}(\%)$ & \\
\hline$\overline{\text { All }}$ & Both & 38 & 8 & 8 & 32 & 7.8 & 11.3 \\
\hline All & Spring & 21 & 3 & 12 & 32 & 7.1 & 9.8 \\
\hline \multirow[t]{2}{*}{ All } & Fall & 17 & 9 & 8 & 30 & 6.3 & 12.0 \\
\hline & & & 8 & 10 & 32 & 8.6 & \\
\hline ATTA & Both & 3 & 8 & 2 & 32 & 4.5 & 10.6 \\
\hline CHAS & Both & 4 & 8 & 14 & 26 & 7.7 & 10.3 \\
\hline \multirow[t]{2}{*}{ CLEM } & Both & 6 & 5 & 14 & $26-36$ & 8.3 & 14.3 \\
\hline & & & 8 & 10 & 34 & 9.9 & \\
\hline FLET & Both & 7 & 8 & 14 & 30 & 4.2 & 6.7 \\
\hline LEWI & Both & 9 & 8 & 8 & 30 & 5.6 & 7.5 \\
\hline PLNS & Both & 5 & 8 & 16 & 34 & 2.3 & 12.9 \\
\hline \multirow[t]{2}{*}{ ATTA } & Fall & 2 & 9 & 4 & 34 & 0.1 & 13.5 \\
\hline & & & 8 & 4 & $34-36$ & 0.2 & \\
\hline \multirow[t]{4}{*}{ CHAS } & Spring & 2 & 2 & 16 & $26-36$ & 8.7 & 13.6 \\
\hline & & & 8 & 16 & 36 & 9.2 & \\
\hline & Fall & 2 & 3 & 0 & 26 & 0.5 & 0.9 \\
\hline & & & 8 & 0 & 26 & 3.3 & \\
\hline \multirow[t]{3}{*}{ CLEM } & Spring & 4 & 8 & 0 & 34 & 7.0 & 7.2 \\
\hline & Fall & 2 & 4 & 14 & 30 & 0.6 & 28.7 \\
\hline & & & 8 & 16 & 32 & 5.5 & \\
\hline \multirow[t]{4}{*}{ FLET } & Spring & 2 & 4 & 2 & 34 & 0.02 & 6.7 \\
\hline & & & 8 & 0 & 36 & 0.07 & \\
\hline & Fall & 5 & 4 & 16 & 28 & 3.0 & 7.5 \\
\hline & & & 8 & 16 & 30 & 4.2 & \\
\hline \multirow[t]{2}{*}{ FLOR } & Spring & 3 & 2 & 12 & $26-36$ & 3.2 & 5.6 \\
\hline & & & 8 & 10 & 36 & 3.9 & \\
\hline \multirow[t]{2}{*}{ LEWI } & Spring & 6 & 8 & 16 & 30 & 5.1 & 7.7 \\
\hline & Fall & 3 & 8 & 0 & 36 & 2.5 & 2.8 \\
\hline \multirow[t]{3}{*}{ PLNS } & Spring & 3 & 10 & 8 & $30-34$ & 1.9 & 8.0 \\
\hline & & & 8 & 16 & 34 & 2.4 & \\
\hline & Fall & 2 & 8 & 16 & 34 & 0.01 & 2.3 \\
\hline
\end{tabular}

\footnotetext{
${ }^{\text {a }}$ ATTA, Attapulgus; CHAS, Charleston; CLEM, Clemson; FLET, Fletcher; FLOR, Florence; LEWI, Lewiston; PLNS, Plains; TIFT, Tifton.
} 
location, and from season to season, however, Method 8 had the smallest $\mathrm{CV}$ in $48 \%$ of the 21 analyses (Table 3 ). Further, in eight of the remaining 11 analyses the CV of Method 8 was within 2 percentage points of the best method.

Over all locations and at each location, the $\mathrm{CV}$ was lower for each season than over both seasons, except in spring at Charleston. CVs were also lower in fall seasons than in spring seasons, except at Fletcher where the $\mathrm{CV}$ was smaller over spring seasons (0.02) than over fall seasons (3.0) and Attapulgus and Florence where no data were available to be compared over fall seasons. Over both seasons, CVs were lower at each location than over all locations, except at Clemson where the $\mathrm{CV}$ was larger than that over all locations. Therefore, models developed for a specific site and season will achieve the greatest accuracy for tomatoes as found for peppers by Perry et al. (1993). However, the consistent improvement (reduced variability) of Method 8 when compared with counting days, provides support for recommending this as the heat unit summation technique for this entire region.

\section{Conclusions}

Heat unit summation methods improved harvest date prediction accuracy compared with the counting day method for tomatoes in the SAC region. Prediction using location/season specific models were less variable than the models over all seasons and locations. Incorporating daylength improved model prediction accuracy when applied over all locations and seasons, all locations by season, and all seasons by location. Based on the results of this study, the heat unit summation technique recommended for this region (where the location and season specific models are not available) is Method 8, the reduced ceiling method multiplied by daylength.

\section{References}

Arnold, C.Y., 1959. The determination and significance of the base temperature in a linear heat unit system. Proc. Am. Soc. Hort. Sci., 74: 430-445.

Boswell, V.R., 1929. Factors influencing yield and quality of peas. Maryland Agric. Exp. Sta. Bull. 306, Beltsville.

Calado, A.M. and Portas, C.M., 1987. Base-temperature and date of planting in processing tomatoes. In: W.L. Sims (Editor), Second International Symposium on Processing Tomatoes. Acta Horticulturae, 200.

Dufault, R.J., Decoteau, D.R., Garrett, J.T., Nagata, R.T., Batal, K.D., McLaurin, W.J., Granberry, D.M., Perry, K.B. and Sanders, D.C., 1989. Determination of heat unit requirements for collard harvest in the Southeast United States. J. Am. Soc. Hort. Sci., 114: 898-903.

Hodges, T., 1991. Predicting Crop Phenology. CRC Press, Inc., Boca Raton, FL, 233 pp.

Owens, Jr., T.O. and Moore, E.L., 1974. A comparison of various methods of calculating heat unit requirements of tomato. Technical Bulletin No. 70, Mississippi Agric. and Forestry Experiment Station, Mississippi State University, MS.

Perry, K.B. and Wehner, T.C., 1990. Prediction of cucumber harvest date using a heat unit model. HortScience, 25: 405406.

Perry, K.B., Wehner, T.C. and Johnson, G.L., 1986. Comparison of 14 methods to determine heat unit requirements for cucumber harvest. HortScience, 21: 419-423.

Perry, K.B., Sanders, D.C., Granberry, D.M., Garrett, J.T., Decoteau, D.R., Nagata, R.T., Dufault, R.J., Batal, K.D. and McLaurin, W.J., 1993. Heat units, solar radiation and daylength as pepper harvest predictors. Agric. For. Meteorol., 65: 197205.

Tyldesley, J.B., 1978. A method of evaluating the effect of temperature on an organism when the response is non-linear. Agric. Meteorol., 19: 137-153.

Warnok, S.J., 1970. Tomato heat accumulation at various locations in California. HortScience, 5: 670-671.

Warnok, S.J. and Isaacs, R.L., 1969. A linear heat unit system for tomatoes in California. J. Am. Soc. Hort. Sci., 94: 677-678.

Witter, S.H. and Aung, L.H., 1969. Lycopersicon esculentum Mill. In: L.T. Evans (Editor), The Induction of Flowering. Macmillan of Australia.

Wolf, S., Rudich, J., Marani, A. and Rekah, Y., 1986. Predicting harvesting data of processing tomatoes by a simulation model. J. Am. Soc. Hort. Sci., 111: 11-16. 